\title{
Network Distribution Model of Influenza Virus in the Community
}

\author{
P. Pongsumpun
}

\begin{abstract}
Influenza is occurred around the world. It caused by influenza virus. The types of influenza can affect people such as type $A, B$ and $C$. The influenza virus can spread though the air from coughs or sneezes between people. It can be found in all age of human. In this study, we formulate the network model for the transmission of influenza virus. The numerical simulations are given to see the influence of each parameter.The mathematical method is used in this paper. The discussion of each parameter is given.
\end{abstract}

Index Terms - Community, influenza, model, network.

\section{INTRODUCTION}

An infectious disease is usually found around the world such as influenza. It was found long time ago. Influenza virus has three types,ie. Type A, B and C. Type A has 11 different serotypes such as H1N1, H2N2, H3N2, H5N1, H7N7, H1N2, H9N2, H7N2, H7N3, H10N7, H7N9 [1]-[2]. Influenza A has more common than the other types. The symptoms of influenza patients are high fever, runny nose, sore throat, muscle pains, headache and coughing. Usually, the person who infect the influenza virus can have symptoms after two days of infection [3]. First influenza pandemic occurred in 1918. We called as Spanish flu pandemic type A influenza, H1N1 subtype. That pandemic lasted from 1918 to 1919 . There were about 50 to 100 million people. That pandemic has been described as "the greatest medical holocaust in history" and may have killed as many people as the Black Death [4]. After that, the 1957 flu pandemic or Asian flu (type A influenza, H2N2 subtype was happened in China. This pandemic outbreak was occurred in early 1956 until 1958, which is the H2N2 subtype of influenza A.

Worldwide deaths were varying depending on source, ranging from 1 million to 4 million people. The pandemic in 1968-1970 or Hong Kong flu was relatively mild compared to the Spanish flu. This flu had 2 flu pandemics. It was caused by $\mathrm{H} 3 \mathrm{~N} 2$ strain of influenza A virus which derived from H2N2. This flu affected mainly the elderly and killed approximately one million people in the world [5]-[6]. Then there was the 2009 flu pandemic or swine flu. Dr. Margaret Chan, the director of WHO, announced that the world now at the start of 2009 influenza pandemic. At that time, there were 74 countries and about 30,000 confirmed cases have been reported. According to the data in the United States, mostly patients were young people. The outbreak in Mexico

Manuscript received September 20, 2017; revised December 23, 2017.

P. Pongsumpun is with King Mongkut's Institute of Technology Ladkrabang, Chalongkrung road, Ladkrabang, Bangkok 10520, Thailand (e-mail: kppuntan@kmitl.ac.th). was originated; the number of deaths was over 180 people and the number of patients was 1,614 persons. In 2009, when H1N1 flu outbreak reached Thailand, the Ministry of Public Health assured the Thai people by announcing measures to prevent the spread of H1N1 and establishing the H1N1 Flu Prevention and Control Center. The report on 9 May 2009 in Thailand showed that the first suspected case of the H1N1 flu, who was a person who had traveled back from Mexico. At that time, Thailand became the $31^{\text {st }}$ country in the world with reported cases of the H1N1 flu [7]. In 1988, Flahault et al. [8] studied and formulated the mathematical model describing the transmission of influenza in France. After that, they [9] modified the mathematical model describing the transmission of Influenza in Europe. In 2007, Chowell et al. [10] compared the transmission of Influenza with season in United States, France and Australia by using reproductive number. In 2013, Chong [11] studied the avian influenza by using SIR (Susceptible-Infectious-Recovered) model. In 2014, Pongsumpun et al. [12] formulated the SEIQR (SusceptibleExposed-Infectious-Quarantine-Recovered) model by considering the repetitive contact of H1N1 flu. In this study, we formulate the dynamical model of influenza virus in the community by using SEIQR model to see the distribution of the disease. The numerical solutions of our model are given to see the influence of each parameter to the transmission of this disease.

\section{Mathematical Equations}

In the community, we suppose that there is the school, shop, church, houses, etc.. We assume that there is $\mathrm{M}$ populations in this community. The movement of people is considered by random process. We random the $1^{\text {st }}$ person to the $\mathrm{M}^{\text {th }}$ person (with uniformly distribution) travel in the community everyday. Each person can travel to the school, shop, church, houses, etc. in any day. Each person who lives in any house at the beginning time will come back to his/her house at the ending time. At the first day, the infected human can be in any places in the community. The population in the considered model consists of 5 population classes such as susceptible, exposed, infectious, quarantine and recovered persons. The recovered human can be susceptible to the disease again. The variables and parameters of our model are defined in Table I .

TABLE I: THE VARIABLE AND PARAMETERS IN OUR MODEL

\begin{tabular}{|l|l|}
\hline variable/parameter & Definition \\
\hline $\mathrm{Sh}_{\mathrm{t}, \mathrm{i}}$ & $\begin{array}{l}\text { Number of susceptible human in } \\
\text { the } \mathrm{i}^{\text {th }} \text { place at day } \mathrm{t}\end{array}$ \\
\hline $\mathrm{Eh}_{\mathrm{t}, \mathrm{i}}$ & $\begin{array}{l}\text { Number of exposed human in } \\
\text { the } i^{\text {th }} \text { place at day } \mathrm{t}\end{array}$ \\
\hline $\mathrm{Ih}_{\mathrm{t}, \mathrm{i}}$ & Number of infectious human in \\
\hline
\end{tabular}




\begin{tabular}{|l|l|}
\hline & the $i^{\text {th }}$ place at day t \\
\hline $\mathrm{Qh}_{\mathrm{t}, \mathrm{i}}$ & $\begin{array}{l}\text { Number of quarantine human in } \\
\text { the } \mathrm{i}^{\text {th }} \text { place at day } \mathrm{t}\end{array}$ \\
\hline $\mathrm{IP}$ & $\begin{array}{l}\text { Number of recovered human in } \\
\text { the } i^{\text {th }} \text { place at day } \mathrm{t}\end{array}$ \\
\hline$a_{i}$ & $\begin{array}{l}\text { Incubation period of virus in } \\
\text { human }\end{array}$ \\
\hline$\beta$ & $\begin{array}{l}\text { Distance between the } \mathrm{i}^{\text {th }} \text { place in } \\
\text { the community }\end{array}$ \\
\hline $\mathrm{d}$ & $\begin{array}{l}\text { The transmission rate of virus } \\
\text { between human }\end{array}$ \\
\hline$\alpha$ & $\begin{array}{l}\text { The rate at which the exposed } \\
\text { human can be recovered }\end{array}$ \\
\hline$\lambda$ & $\begin{array}{l}\text { The rate at which the infectious } \\
\text { human can be recovered }\end{array}$ \\
\hline$\theta$ & $\begin{array}{l}\text { The rate at which the infectious } \\
\text { human can be quarantined }\end{array}$ \\
\hline $\mathrm{n}$ & $\begin{array}{l}\text { The rate at which the quarantine } \\
\text { human can be recovered }\end{array}$ \\
\hline $\mathrm{M}$ & $\begin{array}{l}\text { The total number of places in } \\
\text { the community }\end{array}$ \\
\hline & $\begin{array}{l}\text { The total number of human in } \\
\text { the community }\end{array}$ \\
\hline
\end{tabular}

The diagram of our model can be described in the following figure:

The diagram of human population is shown in Fig. 1. The dynamical change of human populations can describe as the following equations:

$$
\begin{aligned}
& \delta \mathrm{Sh}_{\mathrm{t}, \mathrm{i}}=-a_{i} \beta \mathrm{Sh}_{\mathrm{t}, \mathrm{i}}\left(\mathrm{Eh}_{\mathrm{t}, \mathrm{i}}+\mathrm{Ih}_{\mathrm{t}, \mathrm{i}}\right)+\mathrm{c} \mathrm{Rh}_{\mathrm{t}, \mathrm{i}} \\
& \delta \mathrm{Eh}_{\mathrm{t}, \mathrm{i}}=a_{i} \beta S \mathrm{~h}_{\mathrm{t}, \mathrm{i}}\left(\mathrm{Eh}_{\mathrm{t}, \mathrm{i}}+\mathrm{hh}_{\mathrm{t}, \mathrm{i}}\right)-\frac{1}{\mathrm{IP}} \mathrm{Eh}_{\mathrm{t}, \mathrm{i}}-\mathrm{dEh}_{\mathrm{t}, \mathrm{i}} \\
& \delta \mathrm{hh}_{\mathrm{t}, \mathrm{i}}=\frac{1}{\mathrm{IP}} \mathrm{Eh}_{\mathrm{t}, \mathrm{i}}-\alpha \mathrm{Ih}_{\mathrm{t}, \mathrm{i}}-\lambda \mathrm{Ih}_{\mathrm{t}, \mathrm{i}} \\
& \delta \mathrm{Q}_{\mathrm{t}, \mathrm{i}}=\lambda \mathrm{Ih}_{\mathrm{t}, \mathrm{i}}-\theta \mathrm{Qh}_{\mathrm{t}, \mathrm{i}} \\
& \delta \mathrm{Rh}_{\mathrm{t}, \mathrm{i}}=\quad \alpha \mathrm{Ih}_{\mathrm{t}, \mathrm{i}}+\theta \mathrm{Qh}_{\mathrm{t}, \mathrm{i}}+\mathrm{d} \mathrm{Eh}_{\mathrm{t}, \mathrm{i}}-\mathrm{cRh}_{\mathrm{t}, \mathrm{i}}
\end{aligned}
$$

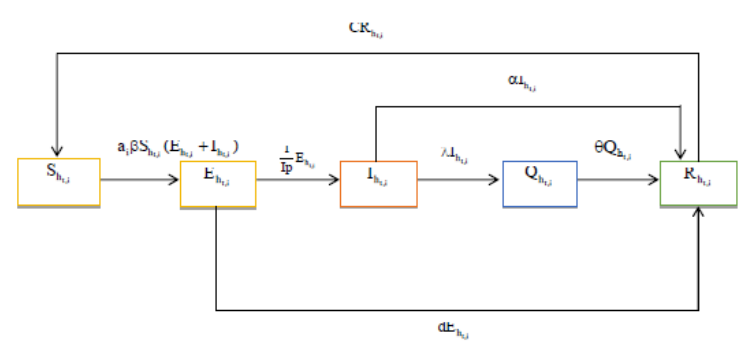

Fig. 1. Diagram of our model.
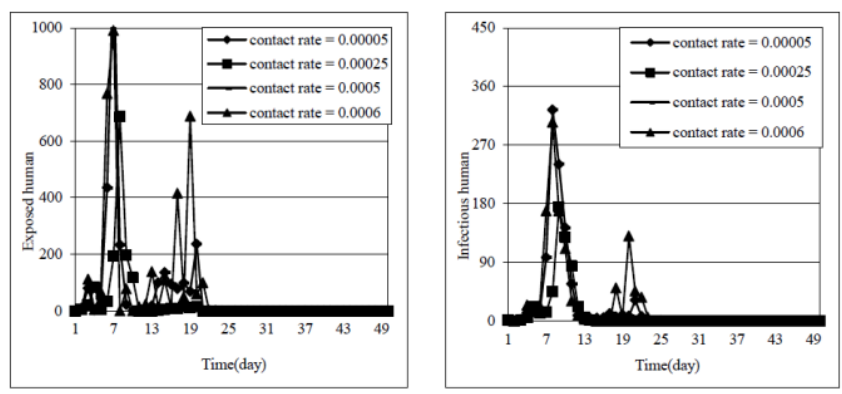

Fig. 2. Simulation outputs of our model. The parameters used in this study are IP $=5$ days, $a_{i}=200$ metres,

$d=1 / 7, \alpha=1 / 14, \lambda=1 / 20, \theta=1 / 6, \mathrm{n}=10, \mathrm{M}=1,000$.
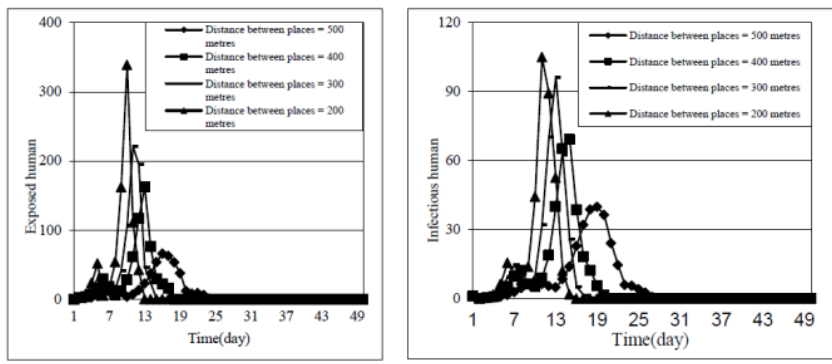

Fig. 3. Simulation outputs of our model. The parameters used in this study are $\mathrm{IP}=5$ days, $\beta=0.00005, d=, 7 / 1, a=1 / 14, \theta=, 6 / 1, \mathrm{n}=10, \mathrm{M}=1,000$.
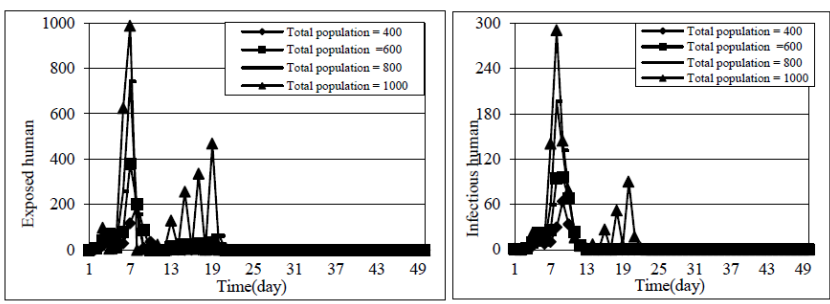

Fig. 4. Simulation outputs of our model. The parameters used in this study are IP $=5$ days, $\beta=0.00005$,

$d=1 / 7, \alpha=1 / 14, \lambda=1 / 20, \theta=1 / 6, \mathrm{n}=10, a_{i}=200$ metres
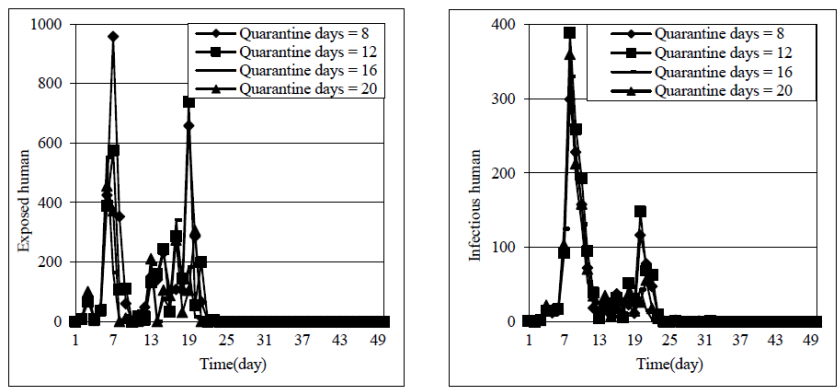

Fig. 5. Simulation outputs of our model. The parameters used in this study are IP $=5$ days, $\beta=0.00005$

$d=1 / 7, \alpha=1 / 14, \theta=1 / 6, \mathrm{n}=10, a_{i}=200$ metres, $\mathrm{M}=1,000$

\section{NUMERICAL SIMULATIONS}

In this section, we simulate our mathematical equations by using numerical analysis. Simulations output of our model are evaluated to see the distribution of the disease. The time distributions of exposed and infectious human for the different situations are shown in the following figures.

\section{DISCUSSION AND CONCLUSIONS}

Mathematical models are used for studying the behaviors of population. In this study, we formulate the dynamical model of influenza to study the network distribution of community. We simulate the model outputs for the different set of parameters. The time series of exposed human and infectious human are shown from fig.2 to fig.6. The contact rate of influenza virus, the distance between places in the community, total population, quarantine day and number of places in the community are considered to be different to see how the parameters effect to the behaviors of population. From Fig. 2 to Fig. 6, we will see that the epidemic size is higher when there is the higher contact rate, the closer place in the community, the greater number of total population, 
the less number of quarantine day and the less number of places in the community. The outburst of epidemic are longer when there is the higher contact rate, longer distance between places, the greater total population, the higher quarantine day and the less number of places. The results of this study should introduce the parameters influencing the behaviors of population in the community.

\section{ACKNOWLEDGMENT}

This work is supported by King Mongkut's Institute of Technology Ladkrabang and National Research Council of Thailand.

\section{REFERENCES}

[1] A. J. Hay, V. Gregory, A. R. Douglas, and Y. P. Lin, "The evolution of human influenza viruses," Philosophical Transactions of the Royal Society B: Biological, vol. 356, pp. 1861-1870, 2001.

[2] M. R. Hilleman, "Realities and enigmas of human viral influenza: Pathogenesis, epidemiology and control," Vaccine, vol. 20, pp. 25-26, 2002.

[3] E. Suzuki, K. Ichihara, and A. M. Johnson, "Natural course of fever during influenza virus infection in children," ClinPediatr (Phila), vol. 46, no. 1, pp. 76-79, 2007.

[4] C. W. Potter, "A history of influenza," Journal of Applied Microbiology, vol. 91, no. 4, pp. 572-579.

[5] M. Mandel, "No need to panic," Toronto Sun, 2009.
[6] W. E. Paul, Fundamental Immunology, Wolters.

[7] Thailand and the H1N1 Flu, Health Issues. Available: www.bangkokbiznews.com/ home/deta. 594.htm

[8] Flahault, S.Letrait et al. Modeling the 1985 influenza epidemic in France, Statistics in Medicine. 7: 1147-1155, 1988.

[9] Flahault, S.Deguen et al. A mathematical model for the European spread of influenza. European Journal of Epidemiology.10: 471-474, 1994.

[10] G. Chowell, M. A. Miller and C. Vibound, "Seasonal influenza in the United Stated, France and Australia: Transmission and prospects for contral," Epidemiology and Infection, vol. 136, pp. 852- 864, 2007.

[11] N. S. Chong, "A mathematical model of avian influenza with halfsaturated incidence," Theory in Biosciences.

[12] P. Pongsumpun and I-Ming Tang, "Dynamics of a new-strain of the $\mathrm{H} 1 \mathrm{~N} 1$ influenza a virus incorporating the effects of repetitive contacts," Computational and Mathematical Methods in Medicine, 2014.

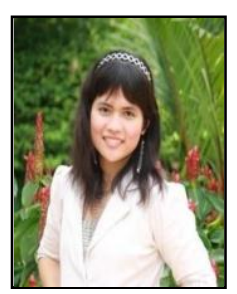

P. Pongsumpun received her bachelor of science in mathematics (second class honors)and the doctor of philosophy in mathematics (international programme) from MahidolUniversity, Thailand From 2004 to 2012, she was an as assistant professor ofmathematics. From 2012 till date, she is an associate professor of mathematics, thesis Ph.D. and M.Sc. advisors in King Mongkut's Institute of Technology Ladkrabang, Thailand.Her research interests are mathematical modelling in medical science, differential equations and numerical analysis. 